\title{
Insuficiencia Cardíaca: una Enfermedad Maligna Conclusiones del Estudio REFERENCE
}

\author{
Heart Failure a Malignant Disease- Insights from the REFERENCE Study
}

\author{
Mário Barbosa, MD, MSc ${ }^{1}$, Andreia Matos, $\mathrm{MSc}^{2,3}$, Manuel Bicho, MD, PhD ${ }^{2,3}$, Luiz Menezes Falcão, MD, PhD ${ }^{3,4,5}$ \\ ${ }^{1}$ Serviço de Medicina Interna, Hospital Lusíadas Lisboa, Portugal. 2Laboratório de Genética e Instituto de Saúde Ambiental-ISAMB, Faculdade de Medicina da Universidade \\ de Lisboa, Portugal. ${ }^{3}$ Instituto de Investigação Científica Bento da Rocha Cabral. ${ }^{4}$ Serviço de Medicina Interna, Hospital de Santa Maria, Lisboa, Portugal. ${ }^{5}$ Faculdade de \\ Medicina da Universidade de Lisboa, Portugal.
}

\begin{abstract}
Aims: Heart failure (HF) short-term prognosis persists poor. We studied the rate of short-term readmission due to $\mathrm{HF}$, short-term all-cause mortality and end of follow-up all-cause mortality.

Material and Methods: We assessed patients admitted with acuteHF in class III or IV of NYHA. Univariate Cox proportional hazard model was performed. Survival curves were plotted using the Kaplan-Meier method and compared with the log-rank test for readmission days post-discharge.

Results: We followed 65 patients for a median of 13.7 (Q1-Q3 6.7-18.9) months. The 30-day post-discharge readmission rate was $13.8 \%$, the 90-day post-discharge readmission percentage was 33.8\% and year readmission rate $61.5 \%$. The 30 -day mortality rate was $10.8 \%$ and 90 day mortality was $18.5 \%$. Year mortality rate was $36.9 \%$ and $40 \%$ of the patients were deceased by the end of the follow-up. Length of stay (LOS) correlated with short-term readmission in the general population (HR: 1.022 , 95\% Cl: 1.009-1.036, P-value<0.001) and in Heart Failure with Reduced Ejection Fraction patients (HFrEF) (HR: 1.029, 95\% Cl: 1.008-1.050, Pvalue $=0.006$ ). The number of hospitalizations correlated with short-term readmission in the general population (HR: 1.543, 95\% Cl: 1.224-1.945, $P$ - value $<0.001)$ and in the Heart Failure with Mid-Range Ejection Fraction subgroup (HFmrEF) (HR: 2.814, 95\% Cl: 1.075-7.365, P- value=0.035). In the Heart Failure with Preserved Ejection Fraction (HFpEF) subgroup both the LOS per specific admission (HR: 1.063, 95\% Cl: 1.006-1.123, $P$ value $=0.030$ ) and the accumulated LOS for all admissions (HR: 1.051, $95 \% \mathrm{Cl}: 1.008-1.095$, $\mathrm{P}$ value $=0.019$ ) were associated with end of followup mortality.

Conclusions: Our findings corroborate the assumption that HF has a poor short-term prognosis. Patients hospitalized longer or repeatedly face a worse outcome.
\end{abstract}

Key words: Acute decompensated heart failure; Prognosis; Short-term readmission; Short-term mortality.

\section{INTRODUCTION}

Ageing of the population due to the prolongation of life span inherent to the improvement in health care, has led to a parallel increase in the rate of chronic heart failure (CHF), making this disease a major and growing public health problem.

These patients have high morbidity and mortality rates due to the fact that cardiac insufficiency per se evolves inexorably, and that it affects an elder and frail population, suffering from multiple comorbidities, polymedicated and often socio-economically vulnerable.

Heart failure has an estimated rate of 1 to $2 \%$ in the adult population $^{1}$, representing the leading cause of admission in Europe and in the United States of America, accounting for 1 to $2 \%$ of all hospitalizations ${ }^{2}$.

The EPICA ${ }^{3}$ trial, dating from 2002, is the only Portuguese HF prevalence study, thus, given the substantial social, economic and

\section{RESUMEN}

Introducción: La insuficiencia cardíaca (IC) tiene un mal pronóstico a corto plazo.Estudiamos las tasas de reingreso precoz por IC, mortalidad global precoz y mortalidad global al final del seguimiento.

Material y métodos: Evaluamos a enfermos ingresados por IC descompensada en clase III o IV de la NYHA. Se utilizó el modelo de riesgo proporcional de Univariante Cox. Se aplicó el método de Kaplan-Meier para obtener curvas de supervivencia para dias de reingreso pós-alta e se comparó al log-rank test.

Resultados: La mediana de seguimiento de los 65 enfermos fue de 13.7 (Q1-Q3 6.7-18.9) meses. La tasa de reingreso a los 30 días del alta fue del $13.8 \%$, a los 90 días del alta fue del $33.8 \%$ y la tasa anual fue del $61.5 \%$. La mortalidad a los 30 días del alta fue del $10.8 \%$ y del $18.5 \%$ a los 90 días. La mortalidad anual fue del $36.9 \%$ y al final del seguimiento del 40\%. La duración del ingreso se correlacionó con el reingreso precoz en la población general (HR: 1.022, 95\% Cl: 1.009-1.036, P-value<0.001) y en el subgrupo con fracción de eyección reducida (HR: 1.029, 95\% Cl: 1.008-1050, P-value=0.006). El número de ingresos fue un marcador de mal pronóstico para el reingreso precoz en la población general (HR: 1.543, 95\% Cl: 1.224-1.945, P-value <0.001) y en el subgrupo con fracción de eyección intermedia (HR: 2.814, 95\% Cl: 1,075-7,365, P-value=0.035). En el subgrupo con fracción de eyección preservadala duración de ingreso por hospitalización (HR: 1.063, 95\% Cl: 1.006-1.123, P value=0.030) y la duración de ingreso acumulada de todas las hospitalizaciones (HR: 1.051, 95\% Cl: 1.008-1.095, P-value=0.019) se correlacionó con la mortalidad al final del seguimiento.

Conclusiones: Nuestros resultados corroboran el concepto de que el pronóstico a corto plazo de la IC es malo.

Los pacientes con hospitalizaciones prolongadas o con múltiples hospitalizaciones tuvieron peor pronóstico.

Palabras clave: Insuficiencia cardíaca descompensada; Pronóstico; Readmisión precoz; Mortalidad precoz.

cultural changes in our country in the past two decades it is crucial to understand the new trends of this overwhelming syndrome.

The real prevalence of HF in Portugal is unknown; additionally the exact number of hospitalizations due to HF is also ignored. ${ }^{4}$ Therefore, faith is deposited in the prevalence study PORTHOS 5 to answer these paramount questions.

Based on the 2011 Portuguese Census, there is an estimated $380000 \mathrm{HF}$ patients in Portugal ${ }^{6}$ and it is estimated that this population will reach half a million individuals in $2035 .{ }^{4}$ In 2014 , HF represented a national economic burden of about 400 million euros and it is estimated that in 2036 this cypher will ascend to 500 million euros. ${ }^{7}$ Notably, admissions are the main responsible for such expenditure. ${ }^{7}$ 
From 2004 to 2012 the number of HF admissions in Portugal increased $33 \%$ and the readmission rate, especially at 30 (14.6\%) and 60 days, also rose. ${ }^{8}$

Early readmissions are mainly related with volume overload, while later rehospitalizations are the consequence of the inevitable progression of this syndrome, which is intrinsically linked to cardiac remodeling. ${ }^{2}$

Patients with $\mathrm{HF}$ have a readmission and mortality rate at 90 days of discharge, respectively 8 and 11 times higher than the general population. ${ }^{9}$

Up to $30 \%$ of patients with HF are readmitted in the first 60 to 90 days after hospital discharge. ${ }^{10} \mathrm{Adding}$ to this matter, is the mortality rate 60 to 90 day post-discharge of about $15 \%$. $^{11}$

Due to its poor outcome, HF could be considered a "malignant disease".12

Bearing in mind that it urges to define short-term prognosis for HF patients, in order to reduce the readmission and premature mortality rates, we performed a prospective cohort study to characterize short-term outcome.

Furthermore, despite the socio-economic relevance that the characterization and acknowledgement of HF short-term prognosis may yield, national trials focusing this topic are scarce.

\section{MATERIAL AND METHODS}

\section{Study design and population}

For this prospective observational cohort study patients were recruited consecutively for a period of 12 months from an Internal Medicine ward of a tertiary care academic hospital.

Inclusion criteria were age $\geq 18$ years old and hospitalization due to chronic decompensated HF in class III or IV of NYHA.

Participants were excluded if they had chronic kidney disease with glomerular filtration rate $<30 \mathrm{ml} / \mathrm{min} / 1.73 \mathrm{~m}^{2}$ (calculated with the Modification of Diet in Renal Disease score) or were under renal replacement therapy, moderate or severe hepatic impairment (calculated with the Child-Pugh score), in-hospital death in the first hospitalization, hospital discharge against medical advice or active cancer with or without metastasis.

All patients gave written informed consent.

The study was approved by an Institutional Review Board (Academic Medical Center Ethics Committee) and followed the Declaration of Helsinki and the Oviedo Convention.

\section{Protocol and definitions}

The diagnosis of HF followed the European Society of Cardiology (ESC) guidelines. ${ }^{1}$

Patient assessment followed a protocol that included clinical history, physical examination, 12-lead ECG, thoracic X-ray, blood sampling for laboratory tests, transthoracic Doppler echocardiography and therapeutic data.

A postero-anterior thoracic $X$-ray was performed with conventional equipment.

A 12-lead ECG was executed using a 3-channel conventional equipmentand all echocardiograms M mode, two-dimensional and Doppler were performed by askilled operator using a Hitachi Aloka alfa 6 Medical device with a $2.5 \mathrm{MHz}$ transducer.

Biochemical parameters were assessed using plasma samples.
Based on the ESC guidelines, HFpEFwas defined as left ventricular ejection fraction (LVEF) $\geq 50 \%$, HFmrHFwas defined as LVEF 4049\% and HFrEFwas classified as LVEF < 40\%.

Treatment was optimized in conformity with the ESC recomendations. $^{1}$

Follow-up was carried out through medical records, discharge reports, death certificates, medical appointments and telephone interviews.

\section{Outcomes}

The outcomes for this study were short-term rehospitalization due to HF, short-termall-cause mortality and end of follow-up all-cause mortality.

Short-term rehospitalization was defined as rehospitalization within 90 days of hospital discharge.

Short-term mortality was defined as death occurring within 90 days after hospital discharge.

End of follow-up mortality was defined as death that occurred during the whole study period.

\section{Statistical analysis}

Categorical variables were summarized by relative and absolute frequencies and compared using the chi-squared test or Fisher's Exact test.

Continuous variables were summarized by mean, standard deviation, median, first and third quartiles (Q1-Q3). Shapiro-Wilk test was used to evaluate the normality of continuous variables.

Comparisons between patients with or without an event of interest were performed using the t-test or Wilcoxon Rank test.

Short-term rehospitalization, short-term mortality and end of followup mortality were considered as stratification variables.

A univariate Cox proportional hazards model was executed to obtain $\mathrm{HR}$ and $95 \% \mathrm{Cl}$ for each variable. The proportional hazards assumption was tested using Schoenfeld residuals. All analyses were conducted at an overall significance level of 5\%.

Survival curves were plotted using the Kaplan-Meier method and compared with the log-rank test for readmission days post-discharge.

\section{RESULTS}

From the 70 selected patients 5 were excluded given that during follow-up they were diagnosed with active neoplasm.

The 65 patients who matched the selection criteria had a median follow-up period of 13.7 (6.7-18.9) months.

The mean age of the patients was $79.2 \pm 10.8$ years and $56.9 \%$ were female.

The mean LVEF was $50.38 \pm 19.07 \%$ and HFpEF accounted for more than half of the population (52.3\%), against HFmrEF (20\%) and HFrEF (27.7\%).

Baseline characteristics of the population study are presented in Table 1.

Descriptive analysis regarding LVEF is depicted in Table 2.

\section{READMISSIONS}

We verified that $33.8 \%$ of the patients were readmitted within 90 days post-discharge, $13.8 \%$ of which in the first 30 days after discharge.

The year readmission percentage was $61.5 \%$. 
Table 1. Baseline characteristics

\begin{tabular}{|c|c|}
\hline Characteristics & Patients $(n=65)$ \\
\hline Age, mean (SD) & $79.2 \pm 10.8$ \\
\hline Female Gender, n (\%) & $37(56.9)$ \\
\hline Hypertension, n (\%) & 58 (89.2) \\
\hline Admission Systolic Blood Pressure, median & $145.0(121-163)$ \\
\hline Type 2 Diabetes, n (\%) & $25(38.5)$ \\
\hline Dyslipidemia, n (\%) & $41(63.1)$ \\
\hline Obesity, n (\%) & $17(26.2)$ \\
\hline Atrial Fibrillation, $n(\%)$ & $28(43.1)$ \\
\hline Ischemic Heart Disease, $\mathrm{n}(\%)$ & $22(33.8)$ \\
\hline Family History of CVD, n (\%) & $31(47.7)$ \\
\hline Tabagism, n (\%) & $21(32.3)$ \\
\hline Anemia, $n(\%)$ & $38(58.5)$ \\
\hline Iron deficiency, n (\%) & $30(46.2)$ \\
\hline Chronic Kidney Disease, n (\%) & $34(52.3)$ \\
\hline GFR (Baseline), median & $57.8(43.8-82.2)$ \\
\hline GFR (Admission), median & $47.9(33.2-68.1)$ \\
\hline LVEF, mean (SD) & $50.38 \pm 19.07$ \\
\hline NYHA class III, n (\%) & $43(66.2)$ \\
\hline ACE Inhibitor, n (\%) & $43(66.2)$ \\
\hline Beta Blocker, n (\%) & $38(58.5)$ \\
\hline Mineralocorticoid Receptor Antagonists n (\%) & $19(29.2)$ \\
\hline Angiotensin II Receptor Blocker, n (\%) & $11(16.9)$ \\
\hline Loop Diuretic, n (\%) & $54(83.1)$ \\
\hline Digoxin, n (\%) & $8(12.3)$ \\
\hline NT-proBNP (Admission), median & $5701.0(1867-11961)$ \\
\hline NT-proBNP (Discharge), median & $2837.0(520-5085)$ \\
\hline
\end{tabular}

Values are median (IQR), $\mathrm{n}(\%)$ or mean $\pm \mathrm{SD}$

IQR: interquartile range and minimum/maximum, SD: standard deviation, CVD: cardiovascular disease, GFR: glomerular filtration rate, LVEF: left ventricular ejection fraction, NYHA: New York Heart Association, ACE: Angiotensin-Converting-Enzyme.
We acknowledged that the mean hospital stay was 8.3 days.

The number of hospitalizations was related with short-term readmission in the general population study (HR: $1.543,95 \% \mathrm{Cl}$ : 1.224-1.945, P-value<0.001) and in the HFmrEF subgroup (HR: 2.814, 95\% Cl: 1.075-7.365, P- value $=0.035)$, and expressed a trend towards greater risk in the HFpEF subgroup (HR: 1.391, 95\% Cl: 0.989-1.956, P-value =0.058, Table 3).

The accumulated LOS for all admissions represented a risk factor for short-term readmission in the general population study (HR: 1.022, 95\% Cl: 1.009-1.036, P-value< $<0.001$, Table 3).

In those suffering from HFrEFshort-term readmission risk, related to the accumulated LOS, was slightly superior to that of the general population study (HR: $1.029,95 \% \mathrm{Cl}: 1.008-1.050$, P-value=0.006, Table 3).For the same subgroup a trend towards the LOS for a given hospitalization and short-term readmission was met (HR: 1.173, 95\% Cl: 0.985-1.395, P-value=0.073, Table 3).

MORTALITY

The 30 -day mortality rate was $10.8 \%$ and the 90 -day mortality rate was $18.5 \%$.Kaplan-Meier curves regarding 30-days post-discharge readmission and 90-days post-discharge readmission are depicted in Figure 1 and Figure 2.

Figure 1. Plot of Kaplan-Meier product limit estimates of survival of heart failure patients according to hospital readmission rate.

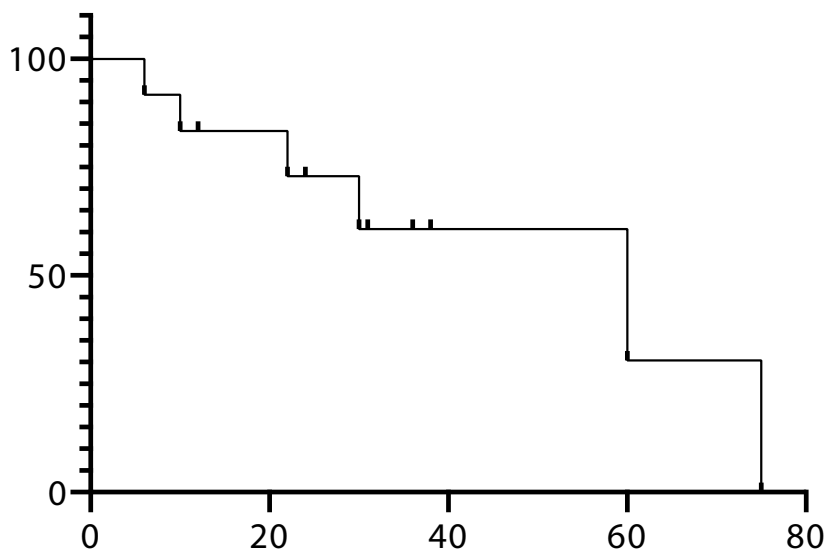

Table 2. Descriptive analysis regarding LVEF

\begin{tabular}{|c|c|c|c|c|c|c|}
\hline \multirow{2}{*}{ LVEF, $\mathrm{n}(\%)$} & \multicolumn{2}{|c|}{ Short-term rehospitalization } & \multicolumn{2}{c|}{ Short-term mortality } & \multicolumn{2}{c|}{ End of follow-up mortality } \\
\cline { 2 - 7 } & $\begin{array}{c}\text { No } \\
(\mathrm{N}=43)\end{array}$ & $\begin{array}{c}\text { Yes } \\
(\mathrm{N}=22)\end{array}$ & $\begin{array}{c}\mathrm{No} \\
(\mathrm{N}=54)\end{array}$ & $\begin{array}{c}\text { Yes } \\
(\mathrm{N}=11)\end{array}$ & $\begin{array}{c}\text { No } \\
(\mathrm{N}=38)\end{array}$ & $\begin{array}{c}\text { Yes } \\
(\mathrm{N}=27)\end{array}$ \\
\hline $\begin{array}{c}\text { Preserved } \\
(>49 \%)\end{array}$ & $24(55.8)[43]$ & $\begin{array}{c}11 \\
(50)[22]\end{array}$ & $\begin{array}{c}31 \\
(57.4)[54]\end{array}$ & $\begin{array}{c}6 \\
(54.5)[11]\end{array}$ & $\begin{array}{c}23 \\
(60.5)[38]\end{array}$ & $\begin{array}{c}12 \\
(44.4)[27]\end{array}$ \\
\hline $\begin{array}{c}\text { Midrange } \\
(40-49 \%)\end{array}$ & $\begin{array}{c}(20.9)[43] \\
(18.2)[22]\end{array}$ & $\begin{array}{c}10 \\
(18.5)[54]\end{array}$ & $\begin{array}{c}2 \\
(18.2)[11]\end{array}$ & $\begin{array}{c}6 \\
(15.8)[38]\end{array}$ & \begin{tabular}{c}
$(25.9)[27]$ \\
\hline
\end{tabular} \\
\hline $\begin{array}{c}\text { Reduced }(< \\
40 \%)\end{array}$ & $10(23.3)[43]$ & $\begin{array}{c}7 \\
(31.8)[22]\end{array}$ & $\begin{array}{c}13 \\
(24.1)[54]\end{array}$ & $\begin{array}{c}3 \\
(27.3)[11]\end{array}$ & $\begin{array}{c}9 \\
(23.7)[38]\end{array}$ & $\begin{array}{c}8 \\
(29.6)[27]\end{array}$ \\
\hline
\end{tabular}

LVEF: left ventricular ejection fraction. $\mathrm{N}$ : number of subjects included in the study,

[n]: number of subjects with available data. 
Table 3. Crude survival analysis for the study population

\begin{tabular}{|c|c|c|c|}
\hline \multirow{2}{*}{ Characteristics } & Short-termrehospitalization & Short-termmortality & End of follow-up mortality \\
\hline & $\mathrm{HR}(95 \% \mathrm{Cl})$ & $\mathrm{HR}(95 \% \mathrm{Cl})$ & $\mathrm{HR}(95 \% \mathrm{Cl})$ \\
\hline \multicolumn{4}{|l|}{ General Population } \\
\hline Length of Stay, days & $\begin{array}{c}0.982 \\
(0.928-1.039)\end{array}$ & $\begin{array}{c}1.009 \\
(0.950-1.071)\end{array}$ & $\begin{array}{c}1.011 \\
(0.974-1.049)\end{array}$ \\
\hline Accumulated Length of Stay, days & $\begin{array}{c}1.022 \\
(1.009-1.036)^{\star \star \star}\end{array}$ & $\begin{array}{c}1.016 \\
(0.999-1.032)\end{array}$ & $\begin{array}{c}1.009 \\
(0.996-1.022)\end{array}$ \\
\hline Number of Hospitalizations & $\begin{array}{c}1.543 \\
(1.224-1.945)^{\star \star \star}\end{array}$ & $\begin{array}{c}1.244 \\
(0.831-1.862)\end{array}$ & $\begin{array}{c}1.062 \\
(0.777-1.453)\end{array}$ \\
\hline \multicolumn{4}{|l|}{ HFpEF } \\
\hline Length of Stay, days & $\begin{array}{c}0.941 \\
(0.832-1.063)\end{array}$ & $\begin{array}{c}1.025 \\
(0.912-1.153)\end{array}$ & $\begin{array}{c}1.063 \\
(1.006-1.123)^{\star}\end{array}$ \\
\hline Accumulated Length of Stay, days & $\begin{array}{c}1.039 \\
(0.990-1.091)\end{array}$ & $\begin{array}{c}0.980 \\
(0.865-1.109)\end{array}$ & $\begin{array}{c}1.051 \\
(1.008-1.095)^{\star}\end{array}$ \\
\hline Number of Hospitalizations & $\begin{array}{c}1.391 \\
(0.989-1.956)\end{array}$ & NC & $\begin{array}{c}0.865 \\
(0.486-0.620)\end{array}$ \\
\hline \multicolumn{4}{|l|}{ HFmrEF } \\
\hline Length of Stay, days & $\begin{array}{c}0.986 \\
(0.903-1.077)\end{array}$ & $\begin{array}{c}0.969 \\
(0.820-1.145)\end{array}$ & $\begin{array}{c}0.956 \\
(0.859-1.065)\end{array}$ \\
\hline Accumulated Length of Stay, days & $\begin{array}{c}1.008 \\
(0.944-1.076)\end{array}$ & $\begin{array}{c}0.932 \\
(0.737-1.179)\end{array}$ & $\begin{array}{c}0.882 \\
(0.740-1.052)\end{array}$ \\
\hline Number of Hospitalizations & $\begin{array}{c}2.814 \\
(1.075-7.365)^{*}\end{array}$ & NC & NC \\
\hline \multicolumn{4}{|l|}{ HFrEF } \\
\hline Length of Stay, days & $\begin{array}{c}1.173 \\
(0.985-1.395)\end{array}$ & $\begin{array}{c}1.080 \\
(0.868-1.345)\end{array}$ & $\begin{array}{c}0.994 \\
(0.838-1.178)\end{array}$ \\
\hline Accumulated Length of Stay, days & $\begin{array}{c}1.029 \\
(1.008-1.050)^{\star \star}\end{array}$ & $\begin{array}{c}1.007 \\
(0.980-1.034)\end{array}$ & $\begin{array}{c}1.006 \\
(0.990-1.022)\end{array}$ \\
\hline Number of Hospitalizations & $\begin{array}{c}1.560 \\
(0.997-2.442)\end{array}$ & $\begin{array}{c}1.062 \\
(0.379-2.977)\end{array}$ & $\begin{array}{c}1.506 \\
(0.994-2.283)\end{array}$ \\
\hline
\end{tabular}

p-value: ${ }^{*}-<0.05 ;{ }^{* \star}-<0.01 ;{ }^{* \star}-<0.001 / \mathrm{NC}$, not calculable due to small number of cases

Figure 2. Kaplan-Meier curves in heart failure patients according to 30-days post-discharge readmission and 90-days post-discharge readmission.

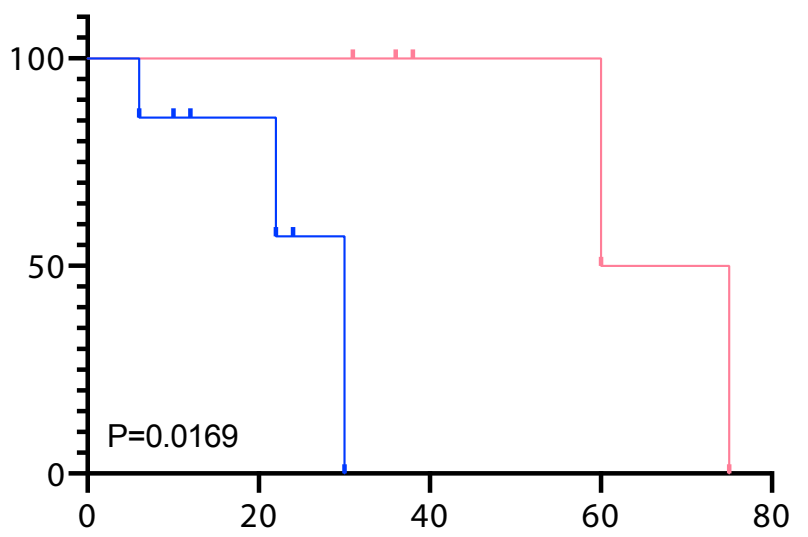

The year mortality was $36.9 \%$ and $40 \%$ of the population study died by the end of follow-up.

A trend towards the accumulated LOS for all admissions and shortterm mortality (HR: 1.016, 95\% Cl: 0.999-1.032, P value $=0.062$, Table 3), was identified in the general population study.

A trend towards the number of hospitalizations and end of follow-up mortality was found in the HFrEF subgroup (HR: 1.506, 95\% Cl: 0.994-2.283, $P$ value $=0.054$, Table 3).

In the HFpEF subgroup both the LOS per specific admission (HR: $1.063,95 \% \mathrm{Cl}: 1.006-1.123, \mathrm{P}$ value $=0.030$ ) and the accumulated LOS for all admissions (HR: 1.051, 95\% Cl: 1.008-1.095, $P$ value $=0.019$, Table 3) were markers of worse end of follow-up survival. 


\section{DISCUSSION}

The characteristics of our population study mimic that of the Portuguese study PRECIC ${ }^{13}$.The aforementioned study observed that HF patients admitted to Internal Medicine departments are elderly, predominantly female and suffer from several comorbidities of which hypertension is, in line with its prevalence, the most frequent.Similarly, ischemic heart disease was the second most prevalent etiology, accounting for around one third of the cases. ${ }^{13}$

Notwithstanding the intrinsic severity of the HF syndrome and the undisputed role of lower LVEF, the burden of comorbidities and older age are, as well, important predictors of impaired outocome. ${ }^{14}$ Importantly, the cited Portuguese study also verified a predominance of HFpEF patients. ${ }^{13}$

Such finding is in syntony with the evolutional pattern of the HF syndrome, since the prevalence of diastolic dysfunction is rising, and currently superior to that of systolic dysfunction, while HFrEF prevalence appears to have declined in the last century. ${ }^{15}$

Moreover, HFpEF affects more frequently women, obese and the elderly, compared to HFrEFand the underlying etiology is, customarily, systemic hypertension. ${ }^{16}$

A Spanish study that addressed HFpEF patients acknowledged that hypertensive heart disease was, also, the most common cause of HF. The authors recognized that such population is typically elderly and have a significant burden of comorbidities. This clinical background determines high readmission and mortality rates. ${ }^{17}$

Another Spanish trial, named PREDICE, also found a population similar to ours; predominantly female, elderly and suffering from a great amount of diseases. ${ }^{18}$

Our study was able to confirm the high early readmission rate of HF patients, as $33.8 \%$ of the population study was rehospitalized within 90 days post-discharge, which is in agreement with several studies. ${ }^{10}$ Remarkably, $15.4 \%$ of the patients were rehospitalized in the first month post-discharge, a rate close to that reported in a large scale series. ${ }^{19}$

The EPICA investigators found that two-thirds of CHF patients are hospitalized, in average, twice in a year. ${ }^{3}$ The year readmission percentage of $61.5 \%$ makes proof of the severity of the clinical cases that we enrolled.

The 30 day mortality rate was $10.8 \%$ similar to the $11.75 \%$ mentioned in the MOCAtrial ${ }^{20}$ and the 90 day mortality rate of $18.5 \%$ was slightly above some series ${ }^{11}$.

The acknowledged year mortality of $36.9 \%$ was superior to that perceived in the PRECIC study (34.3\%) ${ }^{13}$ and to that identified in the LT ESC-HF-LT for the same European region(24.8\%) ${ }^{14}$.

At the end of the follow-up $40 \%$ of the patients were deceased. Albeit we excluded patients with active cancer, which have an elevated mortality, the death rate was overwhelming; this reflects the severity of the HF syndrome.

The LOS for HF patients is estimated to be between four to five days in the mild cases and around nine days in the more severe presentations. $^{21,22}$

In our study the mean hospital stay was 8.3 days, in line with a Portuguese study that enrolled acute decompensated HF patients in a similar clinical scenario. ${ }^{23}$

Furthermore, we recognized that patients hospitalized longer or repeatedly evolved with a worse outcome. Based on these findings, one can conclude that the requirement for hospitalization is a relevant predictor of impaired prognosis as it reflects disease severity. Our assumption finds support in an analysis that studied patients with reduced or preserved LVEF from the CHARM program, which established an association between longer hospitalizations and nonfatal admissions with subsequent mortality rates. ${ }^{24}$

The abovementioned authors also verified an increase in mortality risk after each hospitalization, and the risk was highest after the first month of discharge decreasing progressively over time. ${ }^{24}$

Reynolds et al., suggested that the LOS could be a proxy for the severity of HF since this parameter was related with readmission and mortality within 30 days and 1 year independently of comorbidities and cardiovascular risk factors. ${ }^{25}$

We believe that our findings corroborate the premise that HF has a tremendous social and economic impact.

The progression of HF depends on multiple factors, namely its severity per se, its cause, patient's characteristics, therapeutics and follow-up.

As advocated the first 30 to 90 days post-discharge is a critical period for HF patients and should represent an opportunity to change the syndrome's course.

Given its complexity, strategies to improveshort-term HFprognosis should encompass the optimization of evidence-based treatment, addressing assertively the etiology of HF and concomitant comorbidities, tight follow-up (a multidisciplinary approach and first and foremost the widespread of Heart Failure Day-Hospitals to stabilize patients with minor decompensations preventing the worsening of the condition and inevitably the admission to ward) and patient education.

Our study has limitations that should be taken into account. Due to the small sample size we did not perform multivariable analysis. Besides, our study was a single-center study which may limit the extrapolation of our conclusions.

Despite these potential limitations, this study reports data from a real-world clinical background and the results are consistent with national data and previously published large scale studies, hence supporting the validity of our findings.

\section{CONCLUSIONS}

We acknowledged that the typical HF patient cared for in our department is elderly, belongs to the female gender, has a significant burden of comorbidities and has HFpEF.

Regardless of being, predominantly, an HFpEF population the rate of short-term readmission and mortality was high.

The LOS and hospital readmissions were markers ofadverse shortterm outcome.

These findings corroborate the assumption that HF patients have animpaired short-term prognosis, irrespective of LFEV.

CONFLICTS OF INTEREST AND SOURCE OF FUNDING

OM Pharma, Alfragide, Portugal funded the study.

Dr. Mário Barbosa was granted a research scholarship by AstraZeneca and receives fees for lectures from Novartis.

ETHICAL ASPECTS

The study followed the criteria of the Helsinki Declaration. All participants submitted a consent form to be included in this study. 


\section{REFERENCES}

1. Ponikowski P, Voors AA, Anker SD, Bueno H, Cleland JGF, Coats AJS, et al; Authors/Task Force Members; Document Reviewers. 2016 ESC Guidelines for the diagnosis and treatment of acute and chronic heart failure: The Task Force for the diagnosis and treatment of acute and chronic heart failure of the European Society of Cardiology (ESC). Developed with the special contribution of the Heart Failure Association (HFA) of the ESC. Eur J Heart Fail. 2016 Aug;18(8):891-975.

2. Ambrosy AP, Fonarow GC, Butler J, Chioncel 0 , Greene SJ, Vaduganathan M, et al. The global health and economic burden of hospitalizations for heart failure: lessons learned from hospitalized heart failure registries. J Am Coll Cardiol. 2014 Apr 1;63(12):1123-1133

3. Ceia F, Fonseca C, Mota T, Morais H, Matias F, Sousa A, et al. Rate of chronic heart failure in Southwestern Europe: The EPICA study. Eur J Heart Fail. 2002;4(4):5319.

4. Fonseca C, Brás D, Araújo I, Ceia F.Heart failure in numbers: Estimates for the 21 st century in Portugal. Rev Port Cardiol. 2018;37(2):97-104.

5. Sociedade Portuguesa de Cardiologia prepara estudo sobre insuficiência cardíaca. Jornal Médico. Available from: https://www.jornalmedico.pt/atualidade/39208sociedade-portuguesa-de-cardiologia-prepara-estudo-sobre-insuficienciacardiaca.html.

6. Instituto Nacional de Estatística. Censos 2011: resultados definitivos - Portugal. 2011. Available from: https://censos.ine.pt/ xportal/xmain?xpid=CENSOS\&xpgid=ine_censos_publicacao det\&contexto=pu\&PUBLICACOESpub_boui=73212469\&PUBLICACOESmodo=2\&s elTab=tab1\&pcensos=61969554.

7. Gouveia M, Ascenção R, Fiorentino F, Costa J, Gonçalves P, Fonseca C, et al. Current costs of heart failure in Portugal and expected increases due to population aging. Rev Port Cardiol. 2020;39(1):3-11.

8. Sais C, Lopes H, Completo J,Delgado M, Casas M. IASIST Portugal. Ambulatory care sensitive conditions - impacte do internamento dos doentes crónicos no SNS. 2013. Available from: http://www.iasist.pt/iasist_pt/files/IASIST_ACSC_Dez2013. pdf.

9. Dharmarajan K, Hsieh AF, Kulkarni VT, Lin Z, Ross JS, Horwitz LI, et al. Trajectories of risk after hospitalization for heart failure, acute myocardial infarction, or pneumonia: retrospective cohort study. BMJ. 2015;350:h411.

10. M. Gheorghiade, M. Vaduganathan, G.C. Fonarow, Bonow RO. Rehospitalization for heart failure: problems and perspectives. J. Am. Coll. Cardiol. 2013;61(4):391-403.

11. Vaduganathan M, Fonarow GC, Gheorghiade M. Drug therapy to reduce early readmission risk in heart failure: ready for prime time? JACC Heart Fail. 2013;1(4):361-4.

12. Rocha BM, Menezes Falcão L. Acute decompensated heart failure (ADHF): A comprehensive contemporary review on preventing early readmissions and postdischarge death. Int J Cardiol. 2016;223:1035-1044.
13. Marques I, Abreu S, Bertão M,Ferreira B, Ramos RL, Lopes J, et al. Characteristics and outcomes of heart failure hospitalization before implementation of a heart failure clinic: The PRECIC study. Rev Port Cardiol. 2017;36(6):431-438.

14. Crespo-Leiro M, Anker S, Maggioni A, Coats AJ, Filippatos G, Ruschitzka F, et al. European Society of Cardiology Heart Failure Long-Term Registry (ESC-HFLT): 1-year follow-up outcomes and differences across regions. Eur J Heart Fail. 2016;18(6):613-25.

15. Van Riet EE, Hoes AW, Wagwnaar KP, Limburg A, Landman MAJ, Rutten FH. Epidemiology of heart failure and ventricular dysfunction in older adults over time. A systematic review. Eur J Heart Fail. 2016;18(3):242-52.

16. Fonarow GC, Stough WG, Abraham WT, Albert NM, Gheorghiade M, Greenberg BH, et al. Characteristics, treatments, and outcomes of patients with preserved systolic function hospitalized for heart failure: a report from the OPTIMIZE-HF Registry. J Am Coll Cardiol. 2007;50(8):768-77.

17. Macía-Rodríguez C, Páez-Guillán E, Alende-Castro V, García-Villafranca A, MateoMosquera L, Martínez-Braña L, et al. Five-Year Outcomes of Heart Failure with Preserved Ejection Fraction. The Open Cardiovascular Medicine Journal. 2020; 14: 18-26.

18. Torralba-Morón Á, Guerra-Vales JM, Medrano-Ortega FJ, Navarro-Puerto MA, LoraPablos D, Marín-León I, et al. Renal function at admission as a prognostic marker for patients hospitalised for a first episode of heart failure. Results of the PREDICE study. Rev Clin Esp. 2019; S0014-2565(19):30266-8.

19. Jencks SF, Williams MV, Coleman EA. Rehospitalizations among patients in the Medicare fee-for-service program. N Engl J Med. 2009;360(14):1418-28

20. Lassus J, Gayat E, Mueller C, Peacock WF, Spinar J, Harjola VP,et al. Incremental value of biomarkers to clinical variables for mortality prediction in acutely decompensated heart failure: the Multinational Observational Cohort on Acute Heart Failure (MOCA) study. Int J Cardiol. 2013;168(3):2186-94.

21. Nieminen MS, Brutsaert D, Dickstein K, Drexler H, Follath F, Harjola VP,et al. EuroHeart Failure Survey II (EHFS II: a survey on hospitalized acute heart failure patients: description of population. Eur Heart J. 2006;27(22):2725-36.

22. Fonarow GC, Adams KJ, Abraham WT, Yancy CW, Boscardin WJ;for the ADHERE Scientific advisory committee, study group and investigators. Risk stratification for in-hospital mortality in acutely decompensated heart failure: classification and regression tree analysis. JAMA. 2005;293(5):572-80.

23. Cunha FM, Lourenço P, Couto M, P Tavares, S Silva, J T Guimarães, et al. Is the blood pressure paradox observed in all heart failure patients? Biomed Res Int. 2013;2013:3502-89.Epub 2013 Nov 25

24. Solomon SD, Dobson J, Pocock S, Skali H, McMurray JJV, Granger CB,et al. Influence of nonfatal hospitalization for heart failure on subsequent mortality in patients with chronic heart failure. Circulation. 2007;116(13):1482-7.

25. Reynolds K, Butler MG, Kimes TM, Rosales AG, Chan W, Nichols GA. Relation of Acute Heart Failure Hospital Length of Stay to Subsequent Readmission and AllCause Mortality. Am J Cardiol. 2015;116(3):400-5. 